\title{
TINGKAT KEBISINGAN DI KAWASAN PERMUKIMAN SEKITAR PLTD MUARA TEWEH
}

\author{
Uswatun Hasanah, Zulfikar Ali As, Maharso \\ Jurusan Kesehatan Lingkungan Poltekkes Kemenkes Banjarmasin \\ Jl.H.M.Cokrokusumo No.1A Kota Banjarbaru \\ Email: zulyan03@gmail.com
}

\begin{abstract}
Level of Noise in the residential around muara teweh's PLTD.Muara Teweh's PLTDwas one of the regional companied responsible for the provision of electricity serviced. The impact of the operation of the PLTD is the emergence of noise caused by the PLTD engine so that it appeared on public complainted, especially communication disordered, disordered of physiological and psychological disordered. This study aims to determine the noise level and subjective complainted felt in residential areas around Muara Teweh's PLTD. This research was a descriptive observational describe the noise level in residential areas Muara Teweh's PLTD. This study include cross-sectional design that aims to determine the noise until at residential areas around Muara Teweh's PLTD and connect with public complainted in residential areas around Muara Teweh's PLTD. The measurement resulted show noise levels in residential areas around Muara Teweh's PLTD exceeded the NAV according KEPMEN / LH / 48/1996, which is $62.9 \mathrm{dBA}$ in the North, $70.4 \mathrm{dBA}$ in the Northeast, $69.3 \mathrm{dBA}$ in the East, $69.4 \mathrm{dBA}$ in the direction of the Southeast, $72.3 \mathrm{dBA}$ in the south, $72.2 \mathrm{dBA}$ in the direction of the Southwest, 78.2 in the West and $75.5 \mathrm{dBA}$ in the northwest. Subjective complainted of the most widely felt in residential areas Muara Teweh's PLTD form (45.9\%), headache (56.8\%), discomfort (91.9\%), insomnia (83.8\%) fast and emotions (40.5\%). Efforts should be madeto controlnoise levelsand complaintsaregiving them the toolsnoise suppressioninengine room, thickenthe barrier, put upcurtainsat thewindows of the houseanddo notoftenopen thedoor.
\end{abstract}

Keywords : Noisy environment, residential noise

\begin{abstract}
Abstrak: Tingkat Kebisingan di Kawasan Permukiman Sekitar PLTD Muara Teweh. PLTD Muara Teweh merupakan salah satu perusahaan daerah yang bertanggung jawab dalam penyediaan pelayanan ketenagalistrikan. Dampak pengoperasian PLTD adalah timbulnya kebisingan yang diakibatkan suara mesin diesel sehingga muncul keluhan masyarakat terutama gangguan komunikasi, gangguan fisiologis dan gangguan psikologis. Penelitian ini bertujuan untuk mengetahui tingkat kebisingan dan keluhan subyektif yang dirasakan masyarakat di permukiman sekitar PLTD Muara Teweh. Jenis penelitian ini adalah observasional yang bersifat deskriptif yaitu menggambarkan tingkat kebisingan di permukiman sekitar PLTD. Penelitian ini menggunakan rancangan cross sectional yang bertujuan untuk mengetahui tingkat kebisingan yang sampai di permukiman sekitar PLTD dan menghubungkannya dengan keluhan masyarakat yang bertempat tinggal di sekitar PLTD. Hasil pengukuran menunjukkan tingkat kebisingan di kawasan permukiman sekitar PLTD Muara Teweh melebihi NAB menurut KEPMEN/LH/No.48/1996, yaitu 62,9 dBA di arah Utara, 70,4 dBA di arah Timur Laut, 69,3 dBA di arah Timur, 69,4 dBA di arah Tenggara, 72,3 dBA di arah Selatan, 72,2 dBA di arah Barat Daya, 78,2 di arah Barat dan 75,5 dBA di arah Barat Laut. Keluhan subyektif yang paling banyak dirasakan masyarakat yang bertempat tinggai di sekitar PLTD Muara Teweh berupa berbicara lebih keras $(45,9 \%)$, nyeri kepala $(56,8 \%)$, tidak nyaman $(91,9 \%)$, susah tidur $(83,8 \%)$ dan cepat emosi (40,5\%).Upaya yang dapat dilakukan untuk mengendalikan tingkat kebisingan dan keluhan masyarakat adalah memberi alat peredam bising pada ruang mesin, mempertebal barrier, memasang gorden pada jendela rumah dan tidak sering membuka pintu rumah.
\end{abstract}

Kata kunci $\quad$ : Tingkat kebisingan, Permukiman, Keluhan masyarakat 


\section{PENDAHULUAN}

Polusi suara sekarang diakui di seluruh dunia sebagai masalah utama untuk kualitas hidup di perkotaan. Kebisingan merupakan salah satu penyebab "penyakit lingkungan" yangpenting.World Health Organization (WHO) melaporkan pada tahun 2000 terdapat 250 juta $(4,2 \%)$ penduduk dunia mengalami gangguan pendengaran akibat kebisingan dalamberbagai bentuk. Di Amerika Serikat terdapat sekitar 5-6 juta orang terancammenderita tuli akibat bising. Sedangkan di Belanda jumlahnya mencapai 200.000-300.000orang, di Inggris sekitar 0,2\%, di Canada dan Swedia masing-masing sekitar $0,3 \%$ dariseluruh populasi dan sekitar 75-140 juta (50\%) di Asia Tenggara.Indonesiamenempati urutan ke empat di Asia Tenggara yaitu 4,6\% sesudah Srilanka (8,8\%), Myanmar (8,4\%) dan India (6,3\%). Angka tersebut diperkirakan akan terus meningkat (1).

Tenaga listrik merupakan salah satu kebutuhan yang paling pokok dalam menunjang kehidupan manusia.Perseroan Terbatas Perusahaan Listrik Negara (PT PLN) adalah sebuah Badan Usaha Milik Negara (BUMN) yang memiliki tugas dalam semua aspek kelistrikan di Indonesia terus berupaya meningkatkan profesionalismenya dalam hal pemenuhan kelistrikan.Salah satu pembangkit listrik yang dimiliki oleh PT PLN adalah Pembangkit Listrik Tenaga Diesel (PLTD). Dampak yang ditimbulkan pada proses pengoperasian PLTD adalah timbulnya kebisingan yang diakibatkan dari suara mesin diesel. (2)

PT. PLN (Persero) Wilayah Kalimantan Selatan dan Kalimantan Tengah Cabang Kuala Kapuas PLTD Muara Teweh merupakan salah satu perusahaan daerah yang bertanggung jawab dalam penyediaan pelayanan ketenagalistrikan di Muara Teweh. PLTD Muara Teweh mulai beroperasi pada tahun 1982 dibawah manajemen PT. PLN Cabang Kuala Kapuas yang sampai saat ini memiliki daya terpasang $13.590 \mathrm{~kW}$ dan daya mampu sebesar $9.900 \mathrm{~kW}$. (3)
Data laporan Upaya Pemantauan Lingkungan (UPL) PLTD Muara Teweh semester I tahun 2012 menyatakan bahwa kebisingan ambien (sekitar perusahaan) mencapai 59,9 dBA - 80,3 dBA. Apabila dibandingkan dengan hasil pemantauan kebisingan ambien (sekitar perusahaan) tahun 2011 yang mencapai 59,7 dBA - 77,8 dBA, maka kebisingan di semua titik pengukuran mengalami peningkatan.(3)

Beberapa penelitian melaporkan bahwa operasional PLTD umumnya menimbulkan bising di permukiman dan menyebabkan keluhan masyarakat.Mey Hendra Nurisa Saputra (2006) menuliskan di permukiman sekitar PLTD Kotabaru mencapai 61 dBA - 73 dBA. Begitu pula penelitian yang dilakukan oleh Fuad Nasrullah (2011) menuliskan di permukiman sekitar PLTD Banua Lima Unit Panangkalaan mencapai 52,6 dBA - 68,5 dBA. Tingginya kebisingan ini dipengaruhi oleh jarak rumah dengan sumber bising dan konstruksi rumah yang tidak dapat mereduksi bising.Peningkatan kebisingan PLTD tersebut disertai dengan munculnya keluhan masyarakat terutama gangguan komunikasi, gangguan fisiologis dan gangguan psikologis.

Gangguan kebisingan dibagi dalam dua kategori, yaitu berupa gangguan auditory yaitu gangguan terhadap pendengaran dan gangguan non auditory yaitu gangguan saat berkomunikasi dan menurunnya semangat kerja akibat kelelahan dan stress(4). Dari penelitian Djalante (2010) tingkat kebisingan yang dapat diterima manusia terhadap kesehatan tergantung pada lama kebisingan tersebut yang dipaparkan dan seberapa besar intensitas kebisingan yang memapar.(5)

Tujuan penelitian ini adalah untuk mengetahui tingkat dan sebaran bising di permukiman terdekat dari PLTD Muara Teweh dan keluhan subyektif masyarakat akibat bising PLTD Muara Teweh.

\section{BAHAN DAN CARA PENELITIAN}

Jenis penelitian ini adalah observasional yang bersifat deskriptif. Penelitian dilakukan di kawasan permukiman sekitar PLTD Muara Teweh 
pada bulan Januari sd. Agustus 2015. Populasi dalam penelitian ini adalah terbagi dua yaitu populasi bising (kebisingan yang ada di permukiman kawasan PLTD Muara Teweh) dan populasi keluhan masyarakat yang berada di sekitar tempat penelitian berjumlah $75 \mathrm{KK}$.

Sebagai sampel kebisingan adalah kebisingan yang diukur pada permukiman terdekat dari sumber bising sebanyak 8 titik yaitu arah Utara, Timur Laut, Timur, Tenggara, Selatan, Barat Daya, Barat dan Barat Laut. Penentuan sampel keluhan masyarakat dihitung dengan menggunakam rumus Lemeshow (6) diperoleh sebanyak 37 KK. pengambilan sampel dilakukan dengan carasystematic random sampling yaitu menentukan sampel berdasarkan urutan dari anggota populasi yang telah diberi nomor urut.(7).

Variabel yang diteliti dalam penelitian ini meliputi tingkat kebisingan di permukiman dan keluhan subyektif masyarakat.

Pengumpulan data diperoleh melalui pengukuran kebisingan dilakukan dengan cara sederhana menggunakan alat Sound Level Meteryangdiukur tingkat tekanan bunyi dBA selama 10 menit. Untuk tiap pengukuran, pembacaan dilakukan setiap 5 detik dengan jumlah data yang dikumpulkan adalah 120 buah.Pengukuran dilakukan selama 24 jam yang dibagi 7 periode. Periode-periode tersebut sesuai dengan lampiran Keputusan Menteri Negara Lingkungan Hidup No. 48 Tahun 1996 tentang Baku Tingkat Kebisingan.Memprediksi kebisingan dari aktivitas jalan raya dilakukan dengan cara pencatatan jumlah dan jenis kendaraan bermotor yang melintasi jalan raya pada saat pengukuran kebisingan, juga dilakukan pengamatan dilakukan untuk mengetahui keberadaan barrier yang menjadi penghalang antara sumber bising dengan rumah terdekat.Wawancara dilakukan untuk memperoleh informasi mengenai keluhan subyektif yang dirasakan masyarakat akibat paparan bising yang ditimbulkan oleh mesin-mesin PLTD Muara Teweh. Wawancara dilakukan dengan cara menanyakan pertanyaan secara langsung kepada responden dengan kuesioner.
Pengukuran kebisingan dilakukan untuk memperoleh nilai $\mathrm{L}_{\text {TM5.LTM5 }}$ Ldalah $_{\text {TM }}$ nilai kebisingan yang diperoleh dari 7 periode pengukuran setiap 5 detik selama 10 menit pada masing-masing titik. Adapun rumus yang digunakan adalah sebagai berikut (8) :

Ls dihitung sebagai berikut :

$\mathrm{Ls}=10 \log 1 / 16\left\{\mathrm{~T} 1 \cdot 10^{0,1 \cdot \mathrm{L} 1}+\ldots+\mathrm{T} 4 \cdot 10^{0,1 \cdot \mathrm{L} 4}\right\}$

Lm dihitung sebagai berikut :

$\mathrm{Lm}=10 \log 1 / 8\left\{\mathrm{~T} 5 \cdot 10^{0,1 . \mathrm{L} 5}+\ldots+\mathrm{T} 7 \cdot 10^{0,1 \cdot \mathrm{L} 7}\right\}$

Untuk mengetahui apakah kebisingan sudah melampaui tingkat kebisingan maka perlu dicari nilai Lsm dari pengukuran lapangan. Lsm dihitung dengan rumus :

$$
\begin{aligned}
\mathrm{L}_{\mathrm{SM}}= & 10 \log 1 / 24\left\{16 \cdot 10^{0,1 . \mathrm{Ls}}+\ldots+\right. \\
& 8.10^{0,1(\mathrm{Lm}+5)\}}
\end{aligned}
$$

Keterangan :

Ls = tingkat kebisingan selama siang hari $(\mathrm{dB})$

$\mathrm{Lm}=$ tingkat kebisingan selama malam hari (dBA)

Lsm = tingkat kebisingan selama siang dan malam hari (dBA)

$\mathrm{T}=$ jumlah frekuensi kemunculan $\mathrm{L}$

$\mathrm{L} \quad=$ tingkat kebisingan $(\mathrm{dBA})$

Nilai kebisingan yang terukur akan dikoreksi dengan cara dikurangi dengan nilai perkiraan kebisingan dari jalan raya.

Data keluhan masyarakathasil wawancara ditabulasi dan dikelompokkan menurut kategori yang sejenis kemudian disajikan dalam bentuk tabel dan narasi.

Kondisi lingkungan sekitar PLTDyaitu jarak dan keberadaan barrier disajikan dalam bentuk tabel.Hasil pengukuran tingkat kebisingan di 8 titik sekitar PLTD Muara Teweh dicatat sebagai $\mathrm{L}_{1}$ dengan jarak $d_{1}$, kemudian jarak berikutnya dinyatakan sebagai $d_{2}$ dan tingkat bisingnya sebagai $\mathrm{L}_{2}$ dengan rumus (9) :

$$
\mathrm{L}_{2}=\mathrm{L}_{1}-20 \log \left(\frac{r 2}{r 1}\right)
$$

Keterangan :

$\mathrm{r}_{1}$

(m)

$\mathrm{r}_{2} \quad=$ jarak titik kedua $(\mathrm{m})$

$\mathrm{L}_{1} \quad=$ tingkat bising pada

titik pertama $(\mathrm{dBA})$

$\mathrm{L}_{2} \quad=$ tingkat bising pada

titik kedua $(\mathrm{dBA})$ 
Analisis data dalam penelitian meliputi tingkat kebisingan di permukiman dibandingkan dengan Keputusan Menteri Negara Lingkungan Hidup No. 48 tahun 1996 tentang Baku Tingkat Kebisingan di permukiman yaitu 55 dB. Keluhan masyarakatdihubungkan dengan tingkat kebisingan di permukiman. Kondisi lingkungan sekitar PLTD untuk mengetahui pengaruh jarak dan keberadaan barrier terhadap tingkat kebisingan dan keluhan masyarakat dan perhitungan sebaran bising untuk menetapkan zona permukiman yang memenuhi persyaratan.

\section{HASIL DAN PEMBAHASAN}

PLTD Muara Teweh PT.PLN (PERSERO) Wilayah Kalimantan Selatan dan Kalimantan Tengah Area Kuala Kapuas beroperasi sejak tahun 1976 dengan kapasitas daya terpasang saat ini sebesar $13.590 \mathrm{~kW}$, daya mampu $9.900 \mathrm{~kW}$ dan beban puncak 7650 kW.Pengoperasian mesin berlangsung selama 24 jam dengan beban puncak terjadi antara pukul 17.00 WIB s/d 22.00 WIB.
Kondisi sekitar PLTD Muara Teweh dikelilingi barrier dengan tinggi 10 meter yang terbuat dari bata dan semen.PLTD Muara Teweh terletak di tengah - tengah permukiman penduduk.Jarak permukiman paling dekat dari PLTD adalah $6 \mathrm{~m}$ yang terletak di arah barat.

Permukiman penduduk berada diluar barrier PLTD dengan jarak terdekat $2 \mathrm{~m}$ di arah barat dan $20 \mathrm{~m}$ di arah utara. Berdasarkan hasil pengukuran tingkat kebisingan diseluruh permukiman terdekat sekitar PLTD telah melebihi baku tingkat kebisingan. Kebisingan di kawasan permukiman mencapai 62,9 - 78,2 dBA. Tingkat kebisingan tersebut berada pada lingkungan industri, maka untuk menganalisis keluhan masyarakat di sekitar PLTD digunakan baku tingkat bising kawasan industri yaitu $70 \mathrm{dBA}$.

\section{Tingkat dan Sebaran Bising}

Hasil pengukuran tingkat sebaran bising di permukiman sekitar PLTD Muara Teweh disajikan pada Tabel 1.

Tabel 1. Tingkat Kebisingan di Permukiman Terdekat dari PLTD Muara Teweh Tahun 2015

\begin{tabular}{lccccc}
\hline \multirow{2}{*}{$\begin{array}{c}\text { Arah Pengukuran } \\
\text { dari Sumber }\end{array}$} & \multirow{2}{*}{$\begin{array}{c}\text { Jarak } \\
\text { (m) }\end{array}$} & Level Siang & $\begin{array}{c}\text { Level } \\
\text { Malam }\end{array}$ & $\begin{array}{c}\text { Level Siang } \\
\text { Malam }\end{array}$ & Ket. \\
\cline { 4 - 5 } & 20 & 62,5 & 58,7 & 62,9 & TMS \\
Utara & 15 & 66,7 & 68,7 & 70,4 & TMS \\
Timur Laut & 12 & 67,3 & 66,7 & 69,3 & TMS \\
Timur & 10 & 66,5 & 67,3 & 69,4 & TMS \\
Tenggara & 12 & 72,5 & 72,0 & 72,3 & TMS \\
Selatan & 10 & 68,4 & 70,6 & 72,2 & TMS \\
Barat Daya & 6 & 74,6 & 76,4 & 78,2 & TMS \\
Barat & 9 & 75 & 76,4 & 75,5 & TMS \\
Barat Laut & & & & & \\
\hline
\end{tabular}

Keterangan :

TMS : tidak memenuhi syarat

*Baku mutu tingkat kebisingan sebesar 55 dBA menurut Kepmen-LH No. 48 tahun 1996 tentang Baku Tingkat Kebisingan. 
Adapun titik pengukuran kebisingan di sekitar PLTD Muara Teweh dapat dilihat pada gambar berikut:

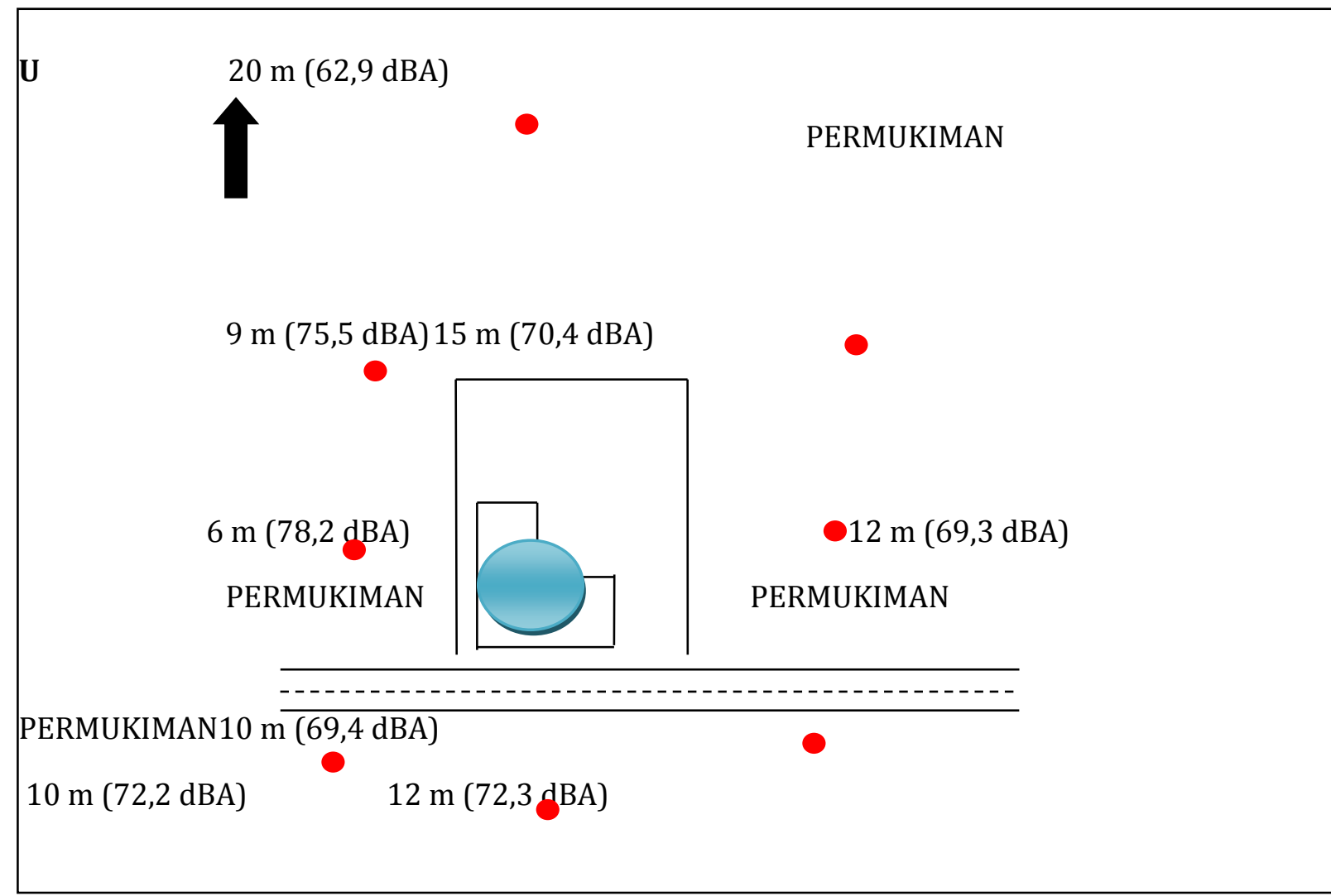

Gambar 1. Sebaran Bising Sekitar PLTD Muara Teweh Tahun 2015

Keterangan :

$$
\begin{aligned}
& =\text { titik pengukuran } \\
& =\text { sumber bising } \\
\overline{\overline{---}} & =\text { barrier } \\
& =\text { jalan raya }
\end{aligned}
$$

Pengukuran kebisingan menunjukkan bahwa kawasan permukiman sekitar PLTD Muara Teweh tingkat kebisingan lebih dari 55 dBA. Hal ini dapat dikatakan bahwa kebisingan yang ditimbulkan PLTD Muara Teweh telah mencapai daerah permukiman penduduk dan menyebabkan kebisingan melebihi yang dipersyaratkan sesuai dengan Keputusan Menteri Lingkungan Hidup No. 48 tahun 1996 tentang baku tingkat bising.

Tingkat kebisingan yang dihasilkan di permukiman terdekat sekitar PLTD Muara Teweh bervariasi berdasarkan jarak antara PLTD dengan permukiman. Jarak terdekat adalah $6 \mathrm{~m}$ yang merupakan lokasi paling tinggi tingkat kebisingannya yaitu 78,2 dBA.
Sedangkan jarak terjauh adalah $20 \mathrm{~m}$ dengan tingkat kebisingan paling rendah yaitu 62,9 dBA. Berdasarkan kenyataan tersebut, dapat dinyatakan bahwa jarak rumah berpengaruh dengan tingkat kebisingan lingkungan.

Tingginya kebisingan di permukiman sekitar PLTD Muara Teweh juga disebabkan oleh kapasitas mesin PLTD Muara Teweh. Mesin yang dioperasikan sampai saat ini sebanyak 15 unit dengan daya 20.000 volt yang memiliki 2 cerobong masing - masing di arahkan ke sebelah Timur dan Barat. Mesin-mesin tersebut di kumpulkan di suatu ruangan khusus yang memiliki peredam getaran namun tidak memiliki peredam bising. Oleh sebab itu, bising yang 
dihasilkan dari mesin-mesin PLTD sampai ke permukiman dan tingkat kebisingannya masih melebihi baku mutu.

Perhitungan jarak permukiman disekitar PLTD, diketahui jarak hipotetik sebaran bising sekitar PLTD Muara Teweh tahun 2015 seperti disajikan pada Tabel 2 .

Tabel 2. Jarak Hipotetik Sebaran Bising Sekitar PLTD Muara Teweh Tahun 2015

\begin{tabular}{lccc}
\hline \multirow{2}{*}{ Arah } & \multicolumn{2}{c}{ Bising Lingkungan } & $\mathbf{d}_{\mathbf{2}}$ \\
\cline { 2 - 3 } & $\mathbf{L}_{\mathbf{1}}(\mathbf{d B A})$ & $\mathbf{d}_{\mathbf{1}}(\mathbf{m})$ & $\mathbf{( m )}$ \\
\hline Utara & 62,9 & 20 & 50 \\
Timur Laut & 70,4 & 15 & 88 \\
Timur & 69,3 & 12 & 62 \\
Tenggara & 69,4 & 10 & 53 \\
Selatan & 72,3 & 12 & 88 \\
Barat Daya & 72,2 & 10 & 72 \\
\hline
\end{tabular}

\begin{tabular}{llll}
\hline Barat & 78,2 & 6 & 87 \\
Barat Laut & 75,5 & 9 & 65 \\
\hline
\end{tabular}

Keterangan:

$\mathrm{L}_{1}$ : tingkat kebisingan (dBA)

$\mathrm{d}_{1 \text { jarak antara sumber bising dengan rumah }}$ terdekat (m)

$\mathrm{d}_{2}$ : jarak hipotetik sebaran bising $(\mathrm{m})$

Tabel 3 menunjukkan bahwa sebaran bising di permukiman sekitar PLTD Muara Teweh berkisar antara 50 - $88 \mathrm{~m}$ dan arah sebaran bising yang paling jauh adalah Timur Laut dan Selatan.

Adapun pemetaan jarak hipotetik sebaran bising disajikan pada Gambar 1 .

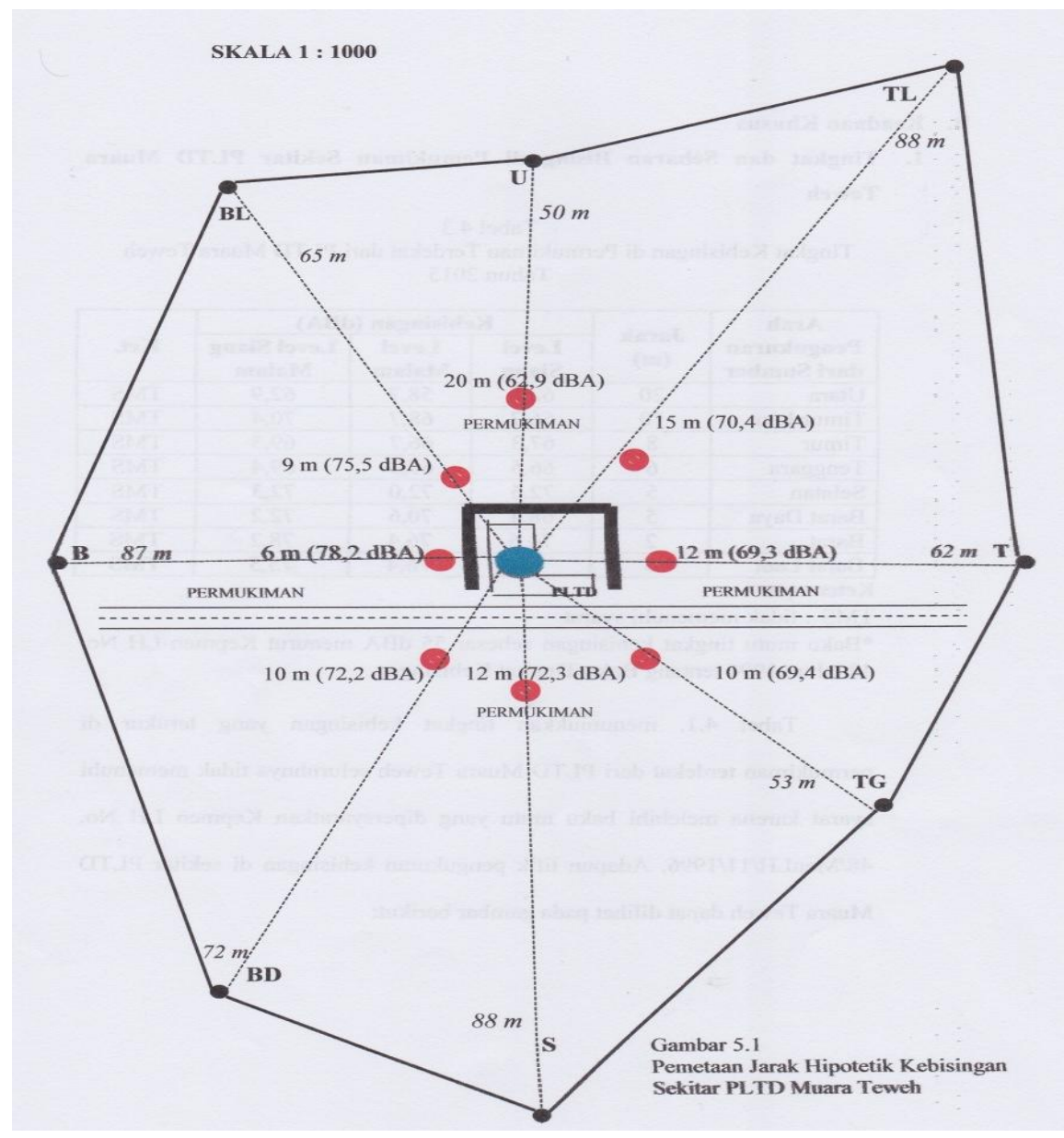

Keterangan :

Gambar 1. Jarak Hipotetik Sebarab Bising

$$
\begin{aligned}
& =\text { titik pengukuran } \\
& =\text { sumber bising } \\
& =\text { titik hipotetik } \\
--- & =\text { jarak hipotetik } \\
& =\text { barrier }
\end{aligned}
$$




$$
\overline{\overline{---}}=\text { jalan raya }
$$

\section{Keluhan Subyektif Masyarakat}

Berdasarkan data tingkat kebisingan dan keluhan masyarakat, dampak kebisingan mulai dirasakan masyarakat pada tingkat kebisingan sebesar $70 \mathrm{dBA}$. Nilai ini lebih tinggi dari baku tingkat kebisingan untuk zona permukiman sebesar 55 dBA. Hal ini dinilai wajar karena pengukuran kebisingan dilakukan di luar bangunan sehingga kebisingan dalam rumah akan lebih rendah.

a. Gangguan Komunikasi

Kebisingan yang ditimbulkan oleh PLTD Muara Teweh menyebabkan 32,4\% responden sulit mendengar pembicaraan secara normal. Hal ini menyebabkan sebagian responden harus mengulang-ulang pembicaraan, berbicara lebih keras, bahkan menggunakan isyarat dalam percakapan. Keluhan yang paling banyak dirasakan responden adalah berbicara lebih keras yaitu $45,9 \%$ sedangkan yang paling sedikit adalah berbicara dengan isyarat sebesar $8,1 \%$.

Hubungan keluhan ini dengan tingkat kebisingan disajikan pada Tabel 3.

Tabel 3.

\begin{tabular}{ccccccccc}
\hline Tingkat kebisingan & \multicolumn{2}{c}{ Bicara keras } & \multicolumn{2}{c}{ Sulit dengar } & \multicolumn{2}{c}{$\begin{array}{c}\text { Menggunakan } \\
\text { isyarat }\end{array}$} & \multicolumn{2}{c}{$\begin{array}{c}\text { Mengulang } \\
\text { pembicaraan }\end{array}$} \\
\cline { 2 - 10 } & ya & tidak & ya & tidak & ya & tidak & ya & tidak \\
$>70 \mathrm{dBA}$ & 17 & 8 & 12 & 13 & 3 & 22 & 4 & 21 \\
$\leq 70 \mathrm{dBA}$ & 0 & 12 & 0 & 12 & 0 & 12 & 0 & 12 \\
\hline
\end{tabular}

Semua gangguan komunikasi muncul pada tingkat kebisingan di atas 70 dBA, diantara keluhan tersebut yang paling banyak dirasakan adalahberbicara lebih keras sebanyak17 responden (68). Sedangkan pada tingkat kebisingan $70 \mathrm{dBA}$ atau kurang tidak ada responden yang menyatakan keluhan serupa.Menurut Kepmen LH No. 48 tahun 1996 (10), kebisingan di atas $60 \mathrm{dBA}$ dikatagorikan sebagai kebisingan sedang dan sudah bersifat mengganggu. Tingkat suara pada level ini merupakan intensitas percakapan pada umumnya, sehingga wajar jika keluhan komunikasi akan muncul saat kebisingan melebihi intensitas percakapan.

b. Gangguan Fisiologis

Gangguan fisiologis yang dirasakan responden yaitu nyeri kepala (56,8\%). Hubungan keluhan ini dengan tingkat kebisingan disajikan pada Tabel 4.

Tabel 4.Gangguan Fisiologis Responden Menurut Tingkat Kebisingan Sekitar PLTD Muara Teweh Tahun 2015

\begin{tabular}{cccccccccc}
\hline Tingkat kebisingan & \multicolumn{2}{c}{ Nyeri kepala } & \multicolumn{2}{c}{ Lelah } & \multicolumn{2}{c}{ Jantung } & \multicolumn{2}{c}{ Hipertensi } \\
\cline { 2 - 9 } & ya & tidak & ya & tidak & ya & tidak & ya & tidak \\
\cline { 2 - 10 }$>70 \mathrm{dBA}$ & 20 & 5 & 7 & 18 & 1 & 24 & 6 & 19 \\
$\leq 70 \mathrm{dBA}$ & 1 & 11 & 1 & 11 & 0 & 12 & 4 & 8 \\
\hline
\end{tabular}

Gangguan fisiologis cenderung berhubungan dengan kebisingan yang dirasakan responden adalah nyeri kepala, karena $80 \%$ responden yang terpapar kebisingan $>70$ dBA menyatakan nyeri kepala.Sedangkan kebisingan $\leq 70 \quad \mathrm{dBA}$ hanya $10 \%$ responden yang menyatakan nyeri kepala. Gangguan fisiologis yang lain seperti lelah, sakit jantung dan hipertensi tidak menunjukkan kecenderungan akibat kebisingan.
Semua gangguan fisiologis muncul pada tingkat kebisingan di atas $70 \mathrm{dBA}$, diantara keluhan tersebut yang paling banyak dirasakan adalah antara lainnyeri kepala yaitu 20 responden (80\%). Sedangkan pada tingkat kebisingan $70 \mathrm{dBA}$ atau kurang keluhan yang paling banyak dirasakan adalah hipertensi yaitu 4 responden. Menurut teori bahwa pengaruh bising akan menimbulkan gangguan fisiologis yaitu kenaikan metabolisme, 
keringat tangan dan kaki, gaya refleks dan kenaikan tekanan darah (10)

Pada tingkat kebisingan $>70 \mathrm{dBA}$ sebanyak $28 \%$ responden menyatakan cepat lelah dan $4 \%$ responden merasa sakit jantung. Sedangkan pada kebisingan $\leq 70$ dBA sebanyak $10 \%$ responden merasa cepat lelah. Sesuai dengan teori bahwa tingkat kebisingan yang mencapai $60 \mathrm{dBA}-65 \mathrm{dBA}$ menimbulkan kelelahan mental, fisik psikosomatis, menjengkelkan dan menimbulkan sakit jantung.

c. Gangguan Psikologis

Gangguan psikologis yang dirasakan responden menunjukkan bahwa gangguan psikologis yang dirasakan oleh responden sekitar PLTD Muara Teweh hampir seluruhnya merasa tidak nyaman $(91,9 \%)$.

Hubungan keluhan ini dengan tingkat kebisngan disajikan pada Tabel 5.

Tabel 5. Gangguan Psikologis Responden Menurut Tingkat Kebisingan Sekitar PLTD Muara Teweh Tahun 2015

\begin{tabular}{ccccccccccccc}
\hline $\begin{array}{c}\text { Tingkat } \\
\text { kebisingan }\end{array}$ & $\begin{array}{c}\text { Tidak } \\
\text { nyaman }\end{array}$ & \multicolumn{2}{c}{$\begin{array}{c}\text { Susah } \\
\text { tidur }\end{array}$} & Stress & \multicolumn{2}{c}{$\begin{array}{c}\text { Cepat } \\
\text { emosi }\end{array}$} & \multicolumn{2}{c}{$\begin{array}{c}\text { Kurang } \\
\text { konsen } \\
\text { baca }\end{array}$} & \multicolumn{2}{c}{$\begin{array}{c}\text { Kurang } \\
\text { konsen } \\
\text { kerja }\end{array}$} \\
\cline { 2 - 14 } & ya & tidak & ya & tidak & ya & tidak & ya & tidak & ya & tidak & ya & tidak \\
\hline$>70 \mathrm{dBA}$ & 25 & 0 & 23 & 2 & 1 & 24 & 10 & 15 & 8 & 17 & 11 & 14 \\
$\leq 70 \mathrm{dBA}$ & 9 & 3 & 8 & 4 & 0 & 12 & 5 & 7 & 1 & 11 & 1 & 11 \\
\hline
\end{tabular}

Gangguan psikologiscenderung berhubungan dengan tingkat kebisingan yang dirasakan masyarakat adalah tidak nyaman dan susah tidur, karena $100 \%$ responden yang terpapar kebisingan $>70$ dBA menyatakan tidak nyaman dan 92\% responden menyatakan susah tidur. Sedangkan tingkat kebisingan $\leq 70 \mathrm{dBA}$ hanya $75 \%$ responden menyatakan merasa tidak nyaman dan $67 \%$ responden menyatakan susah tidur. Gangguan psikologis yang lain seperti stress, cepat emosi, kurang konsentrasi membaca dan kurang konsentrasi bekerja tidak menunjukkan kecenderungan akibat kebisingan.

Semua gangguan psikologis muncul pada tingkat kebisingan $>70 \mathrm{dBA}$ dan $\leq 70$ dBA yaitu responden merasa tidak nyaman dengan adanya suara bising PLTD. Dari keluhan tersebut dapat dilihat sesuai teori pengaruh bising pada manusia pada Tabel 6 .

Tabel 6. Pengaruh Tingkat Intensitas/Tekanan Suara Terhadap Manusia Secara Fisiologis dan Psikologis

Tekanan

Pengaruh pada Manusia

Suara (dBA)

$\begin{array}{cl}30 \text { - } 40 & \text { Mengganggu orang tidur } \\ 55 & \text { Penyempitan pembuluh darah, frekuensi denyut jantung meningkat. } \\ 60 & \begin{array}{l}\text { Menimbulkan kelelahan mental, dan fisik psikosomatis, mengganggu dan } \\ \text { menjengkelkan. }\end{array} \\ 65 & \begin{array}{l}\text { Bila secara terus menerus dapat menimbulkan sakit jantung dan pembuluh } \\ \text { darah. }\end{array} \\ 80 & \begin{array}{l}\text { Bila secara terus menerus dapat menimbulkan kerusakan pada alat } \\ \text { pendengaran. }\end{array} \\ 90 & \begin{array}{l}\text { Bila terus menerus dapat kehilangan pendengaran permanen, batas waktu } \\ \text { pemaparan 8 jam sehari. }\end{array} \\ 100 & \begin{array}{l}\text { Dalam periode singkat, dengan pendengaran berkurang, dan pada pemaparan } \\ \text { yang lama dapat merusak alat pendengaran, batas waktu pemaparan } 2 \text { jam }\end{array} \\ 120 & \begin{array}{l}\text { Rehari. } \\ \text { Rasa nyeri dan sakit, batas waktu pemaparan kuran dari } 1 / 4 \text { jam sehari. }\end{array} \\ 150 & \text { Kehilangan pendengaran saat ini. }\end{array}$


Upaya mengurangi kebisingan yang sampai di permukiman yaitu mereduksi bising dengan cara membuat peredam bising pada ruang mesin sehingga bunyi yang melebihi baku mutu tidak sampai ke permukiman.Pembuatan barrier atau penyekat untuk menghalangi bunyi yang sampai kepermukiman dengan bahan yang sesuai untuk reduksi bising yang diinginkan.

Penyekat/barrier menurut jenis, tebal dan massa dari bahan yang digunakan seperti pada Tabel 7 .

Tabel 7. Noise ReductionMenurut Jenis, Tebal dan Massa dari Bahan

\begin{tabular}{|c|c|c|c|}
\hline Jenis Bahan & $\begin{array}{l}\text { Tebal } \\
(\mathrm{mm})\end{array}$ & $\begin{array}{c}\text { Massa } \\
(\mathrm{kg} / \\
\left.\mathrm{m}^{2}\right) \\
\end{array}$ & $\begin{array}{c}\text { Noise } \\
\text { Reduction } \\
\text { (dB) }\end{array}$ \\
\hline $\begin{array}{l}\text { Asbestos - } \\
\text { semen }\end{array}$ & 6 & 12 & 26 \\
\hline Bata & 113 & 220 & $35-40$ \\
\hline $\begin{array}{l}\text { Papan / } \\
\text { kayu }\end{array}$ & 18 & 12 & 26 \\
\hline Batako & 75 & 100 & 23 \\
\hline $\begin{array}{l}\text { Plywood / } \\
\text { tripleks }\end{array}$ & 6 & 4 & 21 \\
\hline Alluminium & 1,5 & 5 & 22 \\
\hline
\end{tabular}

Penduduk yang tinggal di sekitar PLTD juga dapat melaksanakan upayaupaya pengurangan kebisingan yang sampai ke rumah masing-masing, misalnya dengan pemasangan gorden pada jendela karena gorden dapat menyerap bising yang diharapkan kebisingan dapat dikurangi.

\section{KESIMPULAN DAN SARAN}

Tingkat kebisingan di permukiman terdekat sekitar PLTD Muara Teweh Tidak Memenuhi Syarat (TMS) atau melebihi baku tingkat kebisingan berdasarkan KEPMEN/LH/No.48/1996.Masyarakat

merasa terganggu baik dari segi komunikasi, fisiologis maupun psikologis. Gangguan komunikasi yang paling banyak adalah berbicara lebih keras, gangguan fisiologis paling banyak adalah nyeri kepala dan gangguan psikologis paling banyak adalah responden merasa tidak nyaman dengan adanya bising yang ditimbulkan mesin PLTD.

Saran yang dapat diberikan yaitu menempatkan peredam suara pada sumber
kebisingan.Membuat barrier sesuai dengan jenis, tebal dan bahan yang digunakan. Misalnya melapisi barrier yang ada dengan papan/kayu yang dapat mereduksi bising 26 dBA.Bagi masyarakat dapat memasang gorden pada jendela rumah, tidak sering membuka pintu rumah dan tidak keluar rumah apabila tidak ada keperluan.

\section{KEPUSTAKAAN}

1. Rahayu, Titiek. 2010. Dampak Kebisingan Terhadap Munculnya Ganggusn Kesehatan.

2. Banitriono, Rendika. 2012.Hubungan Antara Kemampuan Pendengaran dan Radius Rumah Pada Warga Masyarakat di Sekitar PLTD Siantan Hilir.Fakultas Kedokteran Universitas Tanjungpura, Pontianak

3. PLTD Muara Teweh, PT.PLN (Persero) Kuala Kapuas. 2012.Laporan Upaya Pemantauan Lingkungan (UPL) PLTD Muara Teweh.

4. Buchari.2007. Kebisingan Industri dan Hearing Conservation. Universitas Sumatera Utara, Medan.

5. Djalante, S.2010. Analisis Tingkat Kebisingan di Jalan raya yang Menggunakan Alat Pembiri Isyarat Lalu Lintas (APIL) (Studi Kasus : Simpang Ade Swalayan). Jurnal SMARTek.

6. Satwiko, P. 2005.Fisika Bangunan 1 (edisi 2).Andi, Yogyakarta.

7. Nugroho, Slamet.2003. Formulir Survey Dampak Kebisingan. Direktorat PPM \& PL, Depkes, Jakarta.

8. Prasetio, L.1985. Akustik Lingkungan. Erlangga, Jakarta .

9. Sears, M. Zeamansky dan F. W.1999. Fisika untuk Universitas 1 (Mekanika, Panas dan Bunyi). Trimitra Mandiri, Jakarta .

10. MenLH.Baku Kebisingan. Surat Keputusan Menteri Lingkungan Hidup Nomor: Kep-48/MENLH/1996/25. Jakarta : MenLH, 1996. 